\title{
Dopamine Release from Interplexiform Cells in the Retina: Effects of GnRH, FMRFamide, Bicuculline, and Enkephalin on Horizontal Cell Activity
}

\author{
Osamu Umino a and John E. Dowling \\ Department of Cellular and Developmental Biology, The Biological Laboratories, Harvard University, Cambridge, \\ Massachusetts 02138
}

In teleost fish, dopaminergic interplexiform cells provide an intraretinal centrifugal pathway from the inner to the outer plexiform layer, where they make abundant synapses on cone-related horizontal cells. The interplexiform cells receive all their input in the inner plexiform layer from centrifugal fibers and amacrine cells. In fish, centrifugal fibers contain gonadotropin hormone-releasing hormone (GnRH)-like and FMRFamide-like peptides (Munz et al., 1982; Stell et al., 1984), whereas amacrine cells contain a variety of neuroactive substances, including a number of peptides. In this study, we examined the effects of GnRH, FMRFamide, bicuculline, and enkephalin on horizontal cell activity in the white perch retina in an attempt to understand the synaptic inputs to the interplexiform cells.

When the retina was superfused with Ringer's solution containing GnRH, horizontal cells depolarized ( $\sim 10 \mathrm{mV})$, and their responses to small spots increased, whereas their responses to full-field lights decreased. Thus, GnRH closely mimicked the effects of dopamine on horizontal cells. The GnRH antagonist [D-Phe $\left.{ }^{2}, \mathrm{Pro}^{3}, \mathrm{D}-\mathrm{Phe}^{6}\right]-\mathrm{GnRH}$ blocked the effects of $\mathrm{GnRH}$, as did haloperidol. GnRH also had no effect on horizontal cells in retinas treated with 6-hydroxydopamine. The results indicate that GnRH acts by stimulating the release of dopamine from interplexiform cells. FMRFamide alone produced no changes on either the membrane potential or light responses of horizontal cells, but it did suppress the effects of GnRH on horizontal cells in some experiments. FRMFamide also reversed the effects of prolonged darkness on horizontal cell responses.

When bicuculline was applied to the retina, horizontal cells also depolarized $(\sim 10 \mathrm{mV})$, responses to full-field illumination decreased, and responses to small spots increased. Most of the effects of bicuculline were suppressed by haloperidol, indicating that bicuculline also stimulates the release of dopamine from interplexiform cells. Similar results were obtained when $\left[\mathrm{D}-\mathrm{Al} \mathrm{a}^{2}\right]$-met-enkephalinamide was ap-

\footnotetext{
Received Nov. 12, 1990; revised Apr. 22, 1991 ; accepted Apr. 30, 1991.

This work was supported in part by NIH Grant EY-00824. We thank Dr. Yoko Hashimoto for helpful comments on the manuscript. We also thank Patricia Sheppard for preparing the figures and Stephanie Levinson for typing the manuscript.

Correspondence should be addressed to John E. Dowling, The Biological Laboratories, Harvard University, 16 Divinity Avenue, Cambridge, MA 02138.

a Present address: Department of Information Science, Toho University, Chiba, Japan.

Copyright (C) 1991 Society for Neuroscience $0270-6474 / 91 / 113034-13 \$ 05.00 / 0$
}

plied to the retina; horizontal cells depolarized ( $\sim 10 \mathrm{mV})$, responses to full-field stimuli decreased, and responses to the light spots increased. On the other hand, [D-Ala $\left.{ }^{2}\right]-l e u-$ enkephalinamide and $\left[\mathrm{D}-\mathrm{Al} \mathrm{a}^{2}, \mathrm{D}\right.$-Leu $\left.{ }^{5}\right]$-enkephalin had no effects on horizontal cells. Both haloperidol and naloxone blocked the effects of [D-Ala2 ]-met-enkephalinamide on horizontal cells, indicating that $\left[\mathrm{D}-\mathrm{Ala}^{2}\right]$-met-enkephalinamide stimulates dopamine release from interplexiform cells via specific opiate receptors.

Dopaminergic interplexiform cells provide an intraretinal centrifugal pathway from the inner to outer plexiform layers. In fish, they receive all of their input in the inner plexiform layer, whereas they make numerous synaptic contacts onto horizontal cells in the outer plexiform layer (Dowling and Ehinger, 1978). The action of dopamine on teleost horizontal cells has been extensively analyzed; exogenous application of dopamine to the retina depolarizes the cells by several millivolts, decreases light responses evoked by full-field illumination (Hedden and Dowling, 1978; Mangel and Dowling, 1985), and reduces their receptive field size (Negishi and Drujan, 1979; Teranishi et al., 1983; Mangel and Dowling, 1987).

Horizontal cells extend processes widely in the outer plexiform layer (Naka and Rushton, 1967; Kaneko, 1971), and they mediate the antagonistic surround responses of bipolar cells (Werblin and Dowling, 1969; Naka, 1972; Toyoda and Tonosaki, 1978). It has been proposed that dopamine modulates horizontal cell activity and thus the strength of center-surround antagonism in the retina as a function of adaptive state (Mangel and Dowling, 1985). Prolonged darkness appears to release dopamine maximally from the interplexiform cells suppressing horizontal cell activity, whereas steady light decreases dopamine release, resulting in enhanced horizontal cell activity (Yang et al., 1988a,b).

In a number of nonmammalian species, centrifugal fibers project into the retina (Ramon y Cajal, 1911) and terminate along the border of the inner plexiform and inner nuclear layers (Dowling and Cowan, 1966). In teleost fish, centrifugal fibers that originate from the nucleus olfactoretinalis contain two peptides. One is similar to gonadotropin hormone-releasing hormone (GnRH), ${ }^{1}$ and the other, to the tetrapeptide FMRFamide

In mammals, $\mathrm{GnR} H$ has luteinizing hormone-releasing activity and is often called luteinizing hormone-releasing hormone (LHRH). Since in all vertebrates the members of this peptide family have gonadotropin-releasing activity, we refer here to these peptides as members of the GnRH family rather than the LHRH family. 
(Phe-Met-Arg-Phe-NH $\mathrm{NH}_{2}$ Munz et al., 1982; Stell et al., 1984). Zucker and Dowling (1987) found that these centrifugal fibers contact dopaminergic interplexiform cells in fish, as well as certain amacrine cells. Interplexiform cells also receive input from amacrine cells (Dowling and Ehinger, 1978), and a number of neuroactive substances, including several peptides, have been localized to amacrine cells (see Ehinger and Dowling, 1987).

In this article, we report experiments that attempt to provide an understanding of the synaptic inputs to the interplexiform cells and the influence of these synaptic inputs on dopamine release in the retina. To clarify the effects of the centrifugal fibers on the release of dopamine from interplexiform cells, we applied GnRH and FMRFamide to the white perch retina while recording intracellularly from horizontal cells. To clarify the role of amacrine cells in regulating interplexiform cell activity and dopamine release, we examined the effects of the GABA antagonist bicuculline and met-enkephalin on white perch horizontal cells.

We assume here that all of the dopaminergic cells in the teleost retina are interplexiform cells. Dowling and Ehinger (1978) have provided some evidence that this is the case, based on the number of dopamine-containing ascending processes they observed in the goldfish retina, but they could not exclude the possibility that there are some other dopaminergic neurons in the teleost retina. A recent study of Teranishi and Negishi (1988), in which the dopaminergic neurons were stained intracellularly, showed that over $80 \%$ of these cells in the carp retina have ascending processes. Since the ascending processes are fine and not easy to visualize, it is reasonable to conclude that most, if not all, of the dopaminergic cells in the teleost retina are interplexiform cells.

Some results of these studies have been reported in abstract form (Umino and Dowling, 1988).

\section{Materials and Methods}

White perch (Roccus americana), approximately $12-17 \mathrm{~cm}$ in total length, were kept in an aquarium under a $12 \mathrm{hr}$ light/dark cycle. After fish had been in the dark for more than $2 \mathrm{hr}$, they were anesthetized by chilling and decapitated. Their eyes were enucleated, and the retinas were isolated from the pigment epithelium and mounted receptor side up on Millipore filter paper. The preparations were placed in a plastic chamber $(0.8 \mathrm{ml} \mathrm{vol})$ and superfused continuously with an oxygenated solution, whose composition is given below, at a rate of approximately $1.0 \mathrm{ml} /$ min. The superfusion system was designed to allow solution to flow both over and underneath the retina. While being superfused, the retina was light sensitized for a minimum of $10 \mathrm{~min}$ by applying full-field white light flashes of $0.5 \mathrm{sec}$ duration every $10 \mathrm{sec}(-2 \mathrm{log})$ (Yang et al., 1988a). Recordings were made with $4 \mathrm{M} \mathrm{KAC}$-filled glass micro electrodes that had resistances of 20-80 M $\Omega$ when placed in Ringer's solution. Responses were recorded on a penwriter, and exact tracings of these records were used for the illustrations.

The retina was stimulated with full-field and spot $(0.9 \mathrm{~mm})$ white light stimuli, presented as an alternating pair. Each stimulus was 0.5 sec long and delivered every $10 \mathrm{sec}$. The light spot was centered over the electrode. The full-field and spot stimuli were initially adjusted in intensity by interposing neutral filters to give responses of approximately equal amplitude. The unattenuated light intensity was $4 \mu \mathrm{W} / \mathrm{cm}^{2}$, corresponding to $1 \times 10^{13}$ photons $\mathrm{cm}^{-2} \mathrm{sec}^{-1}$ at $500 \mathrm{~nm}$. Responses to full-field light indicate the cell's responsiveness to light stimuli, whereas spot responses probe the receptive field size of the cells. For example, an increase in the response to spot illumination indicates a decrease in the receptive field size. This is because the increase of gap junctional resistance between neighboring cells restricts current flow to neighboring horizontal cells. Some experiments were conducted under conditions of prolonged darkness. For such experiments, the retinal preparations were prepared under very dim red light, not light sensitized, and the recordings were made in a totally darkened room.
The normal Ringer's solution contained $\mathrm{NaCl}(145 \mathrm{~mm}), \mathrm{NaHCO}_{3}$ $(20 \mathrm{~mm}), \mathrm{KCl}(2.5 \mathrm{~mm}), \mathrm{CaCl}_{2}(0.7 \mathrm{~mm}), \mathrm{MgSO}_{4}(0.1 \mathrm{~mm})$, and glucose (20 mm). One drop of $1 \mathrm{~N} \mathrm{HCl}$ per $200 \mathrm{ml}$ solution was also added. The solution was continuously bubbled with $97 \% \mathrm{O}_{2}, 3 \% \mathrm{CO}_{2}$, and maintained at $\mathrm{pH}$ 7.4. No albumin was added to the solution. However, in an attempt to avoid the nonspecific binding of peptides to the walls of the perfusion system, the perfusion system was washed with the solution containing albumin (1\%) before each experiment. Test substances were purchased from the following sources: dopamine, 6-hydroxydopamine, ascorbic acid, pargyline, and $\gamma$-aminobutyric acid (GABA), [D-Ala $\left.{ }^{2}\right]$-leucine enkephalinamide, [D-Ala $\left.{ }^{2}, \mathrm{D}-\mathrm{Leu}^{5}\right]-\mathrm{enkeph}$ -

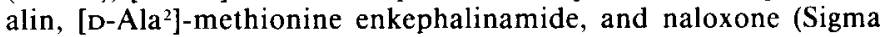
Chemical Co.); bicuculline methochloride (Tocris Chemical, England); haloperidol (Halsol, McNeil Pharmaceutical); albumin, from bovine serum fraction $\mathrm{V}$ (Boehringer Mannheim Biochemicals); mammalian GnRH, [Gln $\left.{ }^{8}\right]$-mammalian GnRH (chicken GnRH), [His $\left.{ }^{5}, \mathrm{Trp}^{7}, \mathrm{Tyr}^{8}\right]$ mammalian GnRH (chicken GnRHII), [Trp? , Leu $\left.{ }^{8}\right]$-mammalian GnRH (salmon GnRH), [Tyr ${ }^{3}$, Leu $^{5}$, Glu $^{6}$, Trp $^{7}$, Lys $\left.^{8}\right]$-mammalian GnRH (lamprey GnRH), [D-Ala $\left.{ }^{6}\right]-$ mammalian $\mathrm{GnRH},\left[\mathrm{D}-\mathrm{Phe}^{2}, \mathrm{Pro}^{3}, \mathrm{D}-\mathrm{Phe}^{6}\right]-$ mammalian GnRH, [D-pGlu ${ }^{1}$, D-Phe' ${ }^{2}$, D-Trp $\left.{ }^{3.6}\right]$-mammalian GnRH, and FMRFamide (Peninsula Laboratories). A new retinal preparation was used for each experiment examining the effects of a chemical agent.

To destroy the dopaminergic interplexiform cells, 6-hydroxydopamine (6-OHDA; $20 \mu \mathrm{g})$, ascorbic acid $(10 \mu \mathrm{g})$, and pargyline $(20 \mu \mathrm{g})$, in a volume of $10 \mu \mathrm{l}$, were injected intraocularly into the vitreous humor of one eye on three successive days about 1 week before eye enucleation (Dowling and Ehinger, 1978; Negishi et al., 1981).

The test agents were applied to the retina by one of two methods. In one, the normal Ringer's solution was completely substituted by the test solution. The second method involved adding a very small amount $(\sim 30 \mu \mathrm{l})$ of concentrated test solution as a pulse into a small chamber that emptied into the main chamber housing the retinal preparation. This method eliminated delays between the preparation of a test agent and its application to the retina. Flow studies using ink demonstrated that test agents introduced into the small chamber reached the main chamber within 1 or $2 \mathrm{sec}$.

The concentration of agents introduced by the second method was estimated as folluws: the volume of solution in the main chamber was about $0.8 \mathrm{ml}$; in the small chamber, about $0.05 \mathrm{ml}$; and in the tube connecting the main chamber and the small chamber, about $0.05 \mathrm{ml}$. Therefore, one drop of test solution (about $0.03 \mathrm{ml}$ ) was diluted about 30 times. However, the superfusion solution was continuously added to the system at a rate of $1.0 \mathrm{ml} / \mathrm{min}$. Thus, the test agent was diluted by more than 30 -fold. Assuming the washout of the test agent from the main chamber took $1 \mathrm{~min}$, we estimated that the test agent would be diluted approximately 60 times. We examined the validity of this estimation by applying mammalian GnRH to the retina using both application methods. The threshold concentration for a GnRH effect on horizontal cells using the first method was about $20 \mu \mathrm{M}$. One drop of a test solution, made by dissolving $0.25 \mathrm{mg} \mathrm{GnRH}$ in $0.15 \mathrm{ml}$ Ringer's solution, also caused a threshold effect on horizontal cells. The estimated concentration of $\mathrm{GnRH}$ reaching the retina was $18.5 \mu \mathrm{M}$ using a dilution factor of 60 , which closely matches the threshold dose $(20 \mu \mathrm{M})$ determined by the first method. Thus, we estimated the concentration of test agents reaching the retina by using this dilution factor. It is important to note that the concentration of test agent reaching the retina by the second, pulse method was never constant. Rather, concentrations first increased, then decreased.

We compared the blocking capability of dopamine antagonists SCH23390, ( \pm )-butaclamol, and haloperidol by examining the effect of externally applied dopamine on the receptive field of horizontal cells in the presence of each antagonist. The antagonists were applied to the rctina for a maximum of $10 \mathrm{~min}$ before dopamine application. Under our experimental conditions, a greater than $7 \mathrm{~min}$ application of $40 \mu \mathrm{M}$ haloperidol was required to block the effect of dopamine, while SCH 23390 only partially blocked the effect of dopamine. $( \pm)$-Butaclamol showed virtually no blocking effect at all under these experimental conditions. Therefore, we chose haloperidol as the antagonist of choice for our experiments.

\section{Results}

The white perch retina possesses four horizontal cell types (Dowling et al., 1985): three are cone related $(\mathrm{H} 1, \mathrm{H} 2, \mathrm{H} 3)$; one is rod related ( $\mathrm{H} 4)$. The $\mathrm{H} 1$ and $\mathrm{H} 2$ cells are luminosity-type 


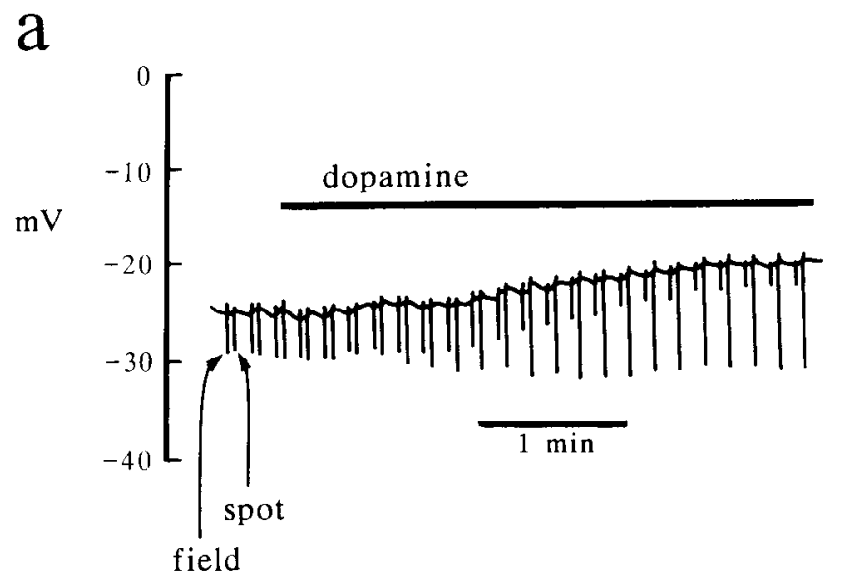

b

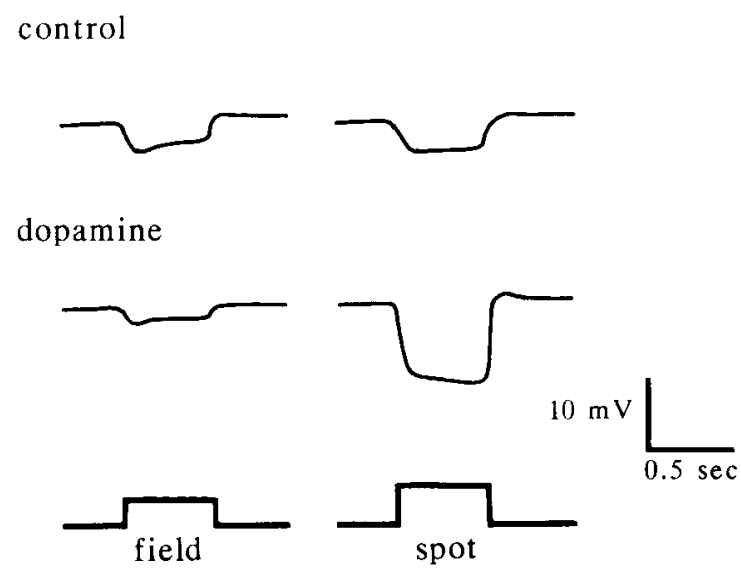

Figure 1. Effects of dopamine $(50 \mu \mathrm{M})$ on a white perch horizontal cell. $a$, Dopamine was continuously applied to the retina during the period indicated by the bar (method 1). Before dopamine application, the fullfield and spot stimuli were adjusted in intensity to yield responses of approximately equal amplitude. Exogenously applied dopamine had two effects on the light-evoked responses: it decreased the response amplitude to full-field illumination, but increased the response amplitude to the spot stimulus. Dopamine also caused a small ( $\sim \mathrm{mV})$ depolarization of the horizontal cell. $b$, Higher-speed recordings of responses to full-field and spot stimuli before and after dopamine application. Log field intensity $\left(I_{F}\right)=-3.9$; $\log$ spot intensity $\left(I_{S}\right)=-2$.

horizontal cells; the $\mathrm{H} 3$ cell is a chromaticity-type cell. The experiments reported here were all carried out on luminositytype cells (i.e., $\mathrm{H} 1$ and $\mathrm{H} 2$ cells). No differences in responses to the drugs were noted between these two cell types.

\section{Dopamine and GnRH}

All horizontal cells responded to the application of dopamine $(n=63)$. Figure 1 shows that exogenously applied dopamine caused three effects on horizontal cells: (1) dopamine generally depolarized the cells by $5-10 \mathrm{mV}$, (2) it decreased the receptive field size of the cells (shown by the increase in the responses to small spot stimuli), and (3) it decreased the overall light responsiveness of the cells (shown by the decrease in amplitude of the responses to full-field light stimuli).

The effects of GnRH on horizontal cells were very similar to those of dopamine (Fig. 2). After GnRH application, horizontal cells typically depolarized $(\sim 10 \mathrm{mV})$, and their responses to small-spot stimuli increased in amplitude, whereas their responses to full-ficld stimuli decrcascd in amplitude. Thesc cffects were consistently observed in 140 retinal preparations tested with GnRH.

Two differences were observed between the effects of GnRH and those of dopamine. First, GnRH required a longer time $(\sim 1 \mathrm{~min})$ to produce effects on horizontal cells as compared with dopamine, which usually required no more than 30-40 sec. Second, the effects of GnRH were usually irreversible even when very low concentrations were applied, whereas the effects of dopamine on horizontal cells were reversible, at least for short durations of drug application.

The threshold concentration for mammalian GnRH was typically $20 \mu \mathrm{M}$, whereas the threshold concentrations for salmon and lamprey GnRH were almost 10 times lower $(\sim 2 \mu \mathrm{M})$. No significant differences were found in the effects of salmon, lamprey, or mammalian GnRH on perch horizontal cell responses. Chicken GnRHII was about as potent as mammalian GnRH, but another chicken $\mathrm{GnRH},\left[\mathrm{Gln}^{8}\right]-\mathrm{GnRH}$, was less effective. [D-Ala ${ }^{6}$-GnRH was slightly less potent than mammalian $\mathrm{GnRH}$, but the difference in threshold concentrations between them could not be determined. The relative potencies of $\mathrm{GnRH}$ analogs were as follows: salmon $\mathrm{GnRH}(n=14)=$ lamprey $\mathrm{GnRH}$ $(n=7)>$ chicken GnRHII $(n=12)=$ mammalian GnRH $(n$ $=30)>$ chicken GnRH $(n=30)$.

An interesting observation was that the threshold concentration for GnRH was decreased in retinas from fish kept in continuous light for 2-3 weeks. An example is shown in Figure 3, in which various concentrations of salmon $\mathrm{GnRH}$ were applied to a retina from a fish kept in the light for $14 \mathrm{~d}$. In this experiment, the threshold concentration was between 0.02 and 0.1 $\mu \mathrm{M}$, which is $10-100$ times lower than the threshold concentration obtained for fish kept under control lighting conditions. The experiment of Figure 3 shows also that the effects of GnRH are concentration dependent. That is, with increasing concentrations of $\mathrm{GnRH}$, the effects on responses to both spot and fullfield illumination correspondingly increased.
Figure 2. The effects of GnRH on a white perch horizontal cell. Mammalian $\mathrm{GnRH}(\sim 40 \mu \mathrm{M})$ was applied as a pulse at the arrow (method 2). Following GnRH application, the cell depolarized by a few millivolts, and responses to spot stimuli increased in amplitude, whereas responses to fullfield illumination decreascd in amplitude. Responses at two recording speeds are shown. Spaces between the recordings represent time periods of less than $10 \mathrm{sec}$. $\log I_{r}=-3.3 ; \log I_{S}=-2.4$.
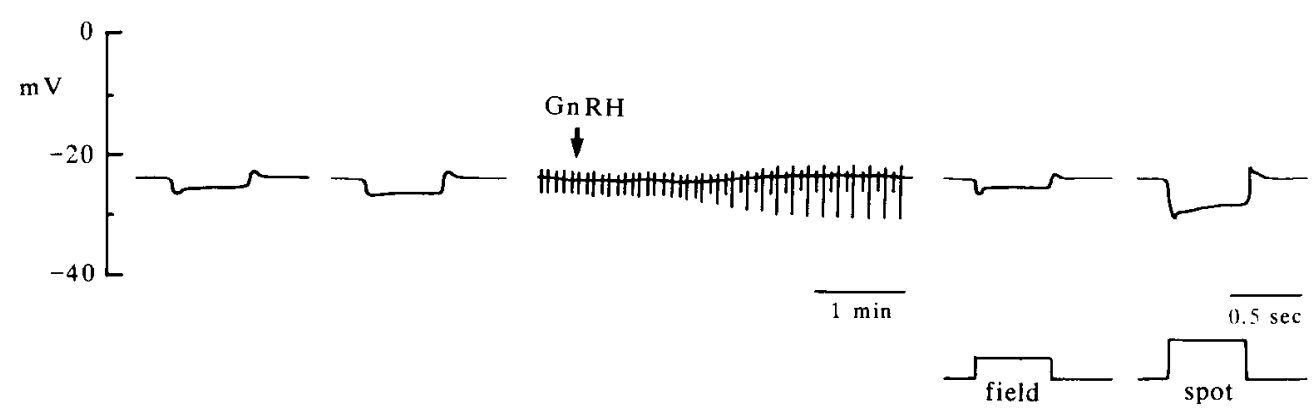
a

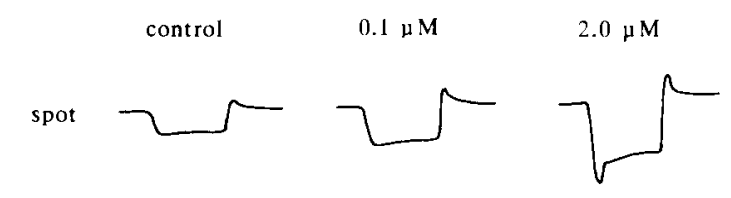

field
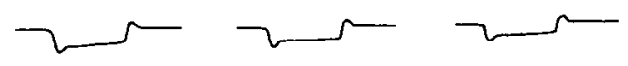

b

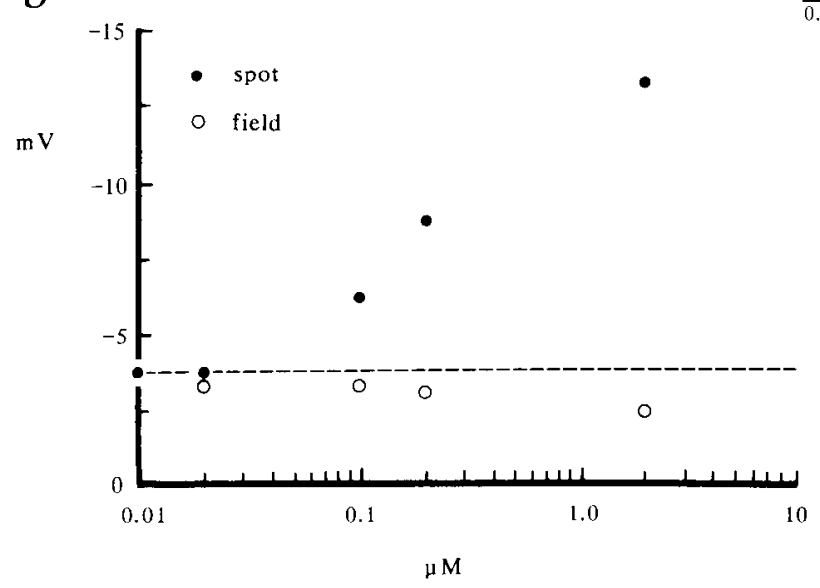

Figure 3. Effects of different GnRH concentrations on light responses of horizontal cells. Fish used in this experiment were kept in the light continuously for 2 weeks. $a$, Responses to spot and full-field stimuli. Increasing concentrations of salmon GnRH were applied in sequence. The intervals of $270-450 \mathrm{sec}$ between the drug applications allowed the effects of each GnRH application to stabilize. Since the effects of GnRH showed no recovery (see Results), each GnRH pulse was applied while the effects of the previous application of GnRH were still evident. $b$, Spot (solid circles) and full-field (open circles) response amplitudes are plotted as a function of GnRH concentrations. The horizontal broken line indicates the response amplitudes to both spot and full-field stimuli before GnRH application. $\log I_{F}=-4.2 ; \log I_{S}=-2.5$.

Figure 4 shows that GnRH had no effect when applied to a retina exposed to the GnRH antagonist [D-Phe ${ }^{2}$, $\mathrm{Pro}^{3}$, D-Phe ${ }^{6}$ $\mathrm{GnRH}(n=3)$. However, another antagonist, [D-pGlu', D-Phe ${ }^{2}$, D-Trp ${ }^{3.6}$-GnRH, was not effective in blocking the effects of GnRH.

\section{GnRH Acts on interplexiform cells}

To test whether GnRH was acting directly on horizontal cells or by promoting the release of dopamine from interplexiform cells, we applied GnRH to horizontal cells in the presence of the dopamine antagonist haloperidol or after depletion of retinal dopamine by 6-OHDA. Figure 5 shows that haloperidol effectively blocked the effects of GnRH on horizontal cells $(n=3)$, and Figure 6 illustrates that GnRH had virtually no effects in 6-OHDA-treated retinas $(n=6)$. The small depolarizations observed in both records were probably unrelated to the application of GnRH. In other experiments, GnRH was applied in the presence of dopamine. Under these conditions, GnRH caused additional membrane depolarization and a slight decrease in response amplitudes to full-field illumination, effects similar to those obtained when additional dopamine was applied to a ret- control

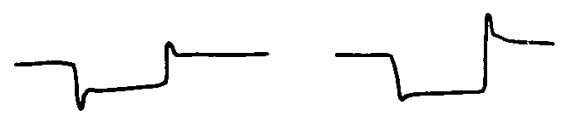

\section{GnRH and GnRH antagonist}
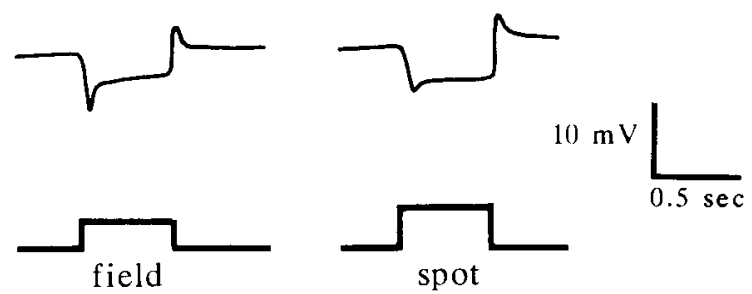

Figure 4. Horizontal cell responses to full-field and spot stimuli before drug application (control; top), in the presence of $40 \mu \mathrm{M}$ of the $\mathrm{GnRH}$ antagonist $\left[\mathrm{D}-\mathrm{Phe}^{2}, \mathrm{PrO}^{3}, \mathrm{D}-\mathrm{Phe}^{6}\right]-\mathrm{GnRH}$ (middle), and in the presence of both the GnRH antagonist ( $40 \mu \mathrm{M})$ and mammalian GnRH ( $40 \mu \mathrm{M}$; bottom). The antagonist by itself caused no significant effects on the light-evoked responses, and it blocked the effects of GnRH. $\log I_{F}=$ $-3.7 ; \log I_{S}=-2.1$.

ina that had been exposed to a nonsaturating concentration of dopamine. These results provide further evidence for the view that GnRH exerts its effects on horizontal cells by stimulating the release of dopamine from interplexiform cells.

\section{FMRFamide}

FMRFamide by itself produced no effects on horizontal cells. Figure 7 shows a typical experiment. FMRFamide was applied at three different concentrations $(10,50$, and $250 \mu \mathrm{M})$, and it had no significant effects. Although small, slow depolarizations were occasionally seen after FMRFamide application, there were no consistent effects on the responses to either field or spot stimuli $(n=20)$. On the other hand, as also shown in Figure 7, bicuculline, an agent that stimulates the release of dopamine from interplexiform cells (see below and Negishi et al., 1983; O'Connor et al., 1986) caused the response to full-field illumination to decrease in amplitude and the response to a spot to increase substantially in size. This experiment eliminated the possibility that the failure of FMRFamide to have an effect was the result of unresponsive interplexiform cells in the retina.

\section{Interactions between GnRH and FMRFamide}

Since GnRH and FMRFamide are both found in the synaptic terminals of the centrifugal fibers (Stell et al., 1984; Zucker and Dowling, 1987), we next tested for possible interactions between FMRFamide and GnRH. As noted above, FMRFamide when applied alone had no effects on horizontal cells. FMRFamide 

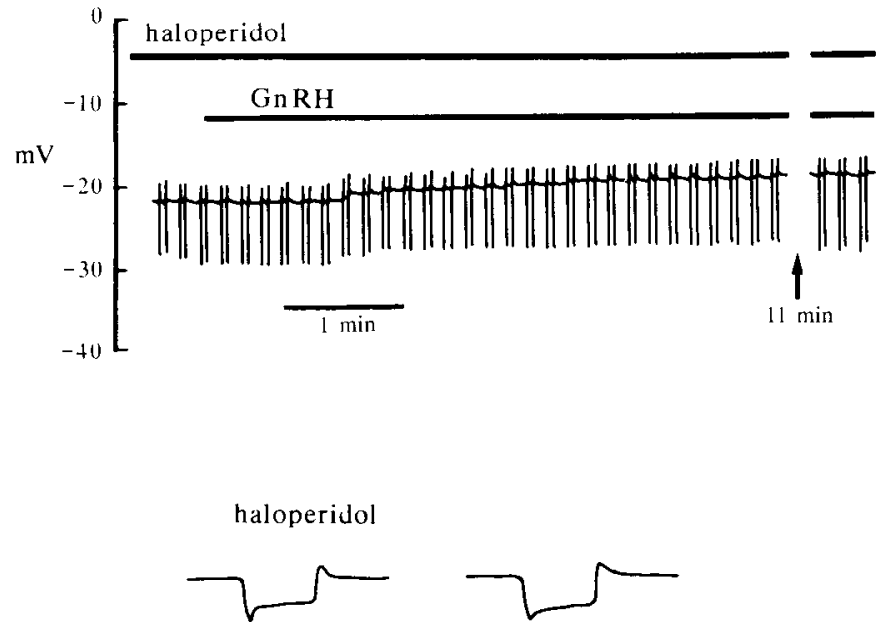

GnRH and haloperidol
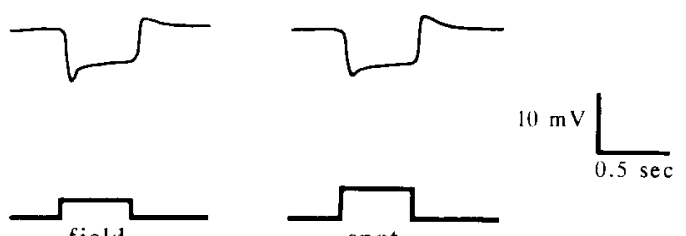

field

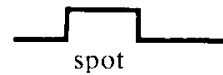

Figure 5. Effects of mammalian GnKH $(40 \mu \mathrm{M})$ when applied in the presence of the dopamine antagonist haloperidol $(50 \mu \mathrm{M})$. The retina was exposed to haloperidol for $30 \mathrm{~min}$ prior to the record shown. The dopamine antagonist completely blocked the effects of GnRH. Top trace, recording at slow speed; bottom trace, recording at high speed. Log $I_{F}$ $=-3.1 ; \log I_{S}=-2.0$.

did, however, antagonize the effects of $\mathrm{GnRH}$ in some experiments. In the experiment shown in Figure 8, GnRH was first applied; it depolarized the cell and caused shrinkage of the receptive field and a reduction of light-responsiveness. Addition of FMRFamide into the perfusion solution containing GnRH resulted in the reversal of the GnRH effects. Thus, FMRFamide caused (1) hyperpolarization of the membrane potential, (2) a reduction in response amplitudes to small-spot stimuli, and (3) an increase in response amplitudes to full-field lights $(n=3)$. In other experiments $(n=3)$, GnRH and FMRFamide were applied simultaneously to the retina, and when the two peptides were applied together, almost no effect on the horizontal cells was observed. In other words, FMRFamide completely blocked the effects of $\mathrm{GnRH}$ in these experiments.

These results indicate that FMRFamide antagonizes the effects of GnRH. However, the antagonistic action of FMRFamide on GnRH was seen only in the late autumn. Identical experiments performed in the spring and summer failed to demonstrate the antagonistic effects of FMRFamide on GnRH. This suggests that the interplexiform cells are not always responsive to FMRFamide (see Discussion).

\section{Effects of FMRFamide under prolonged darkness}

The studies described so far employed the light-sensitized retina (see Yang et al., 1988a). Earlier results from our laboratory indicated that dopamine is maximally released from teleost interplexiform cells under conditions of prolonged darkness (Mangel and Dowling, 1985; Yang et al., 1988a,b), although other investigators do not ascribe to this view (Baldridge et al., 1987; Weiler et al., 1989). Since GnRH stimulates the release of dopamine from interplexiform cells and FMRFamide can block the effect of GnRH, we next tested whether FMRFamide application to the retina affects the responses of horizontal cells under conditions of prolonged darkness.

Such an experiment is shown in Figure 9. Here, effects of FMRFamide on the membrane potential (lower trace) and responsiveness to full-field light stimuli (upper traces) were examined. Light responses were obtained at the times indicated $(a-e)$. Under conditions of prolonged darkness $(>2 \mathrm{hr})$, white perch horizontal cells generate only small responses to all light intensilies (trace $a$ ), indicating a lowering of light responsiveness (Yang et al., 1988a). When a Ringer's solution containing FMRFamide was applied to a prolonged dark-adapted retina, the horizontal cell slowly hyperpolarized over a long time course of approximately $30 \mathrm{~min}$. During the application of FMRFamide, the responsiveness of the horizontal cell progressively increased, as shown in traces $b$ and $c$. After approximately $32 \mathrm{~min}$, the response amplitude to the test light $(\log I=-1)$ was $40 \mathrm{mV}$ (trace $c$ ), which was almost 10 times larger than the control response amplitude (trace $a$ ) to the same light stimulus. $\Lambda$ change of response waveform was also seen; the response was slow originally, but following application of the Ringer's solution containing FMRFamide, an initial transient developed at light onset to some stimulus intensities, as well as a depolarizing rebound at light offset. After $36 \mathrm{~min}$ of exposure to FMRFamide, control Ringer's solution was reintroduced. The membrane potential gradually depolarized, and light responses decreased in amplitude (traces $d$ and $e$ ). The response waveform also slowed measurably. After $70 \mathrm{~min}$, light stimuli were applied repeatedly

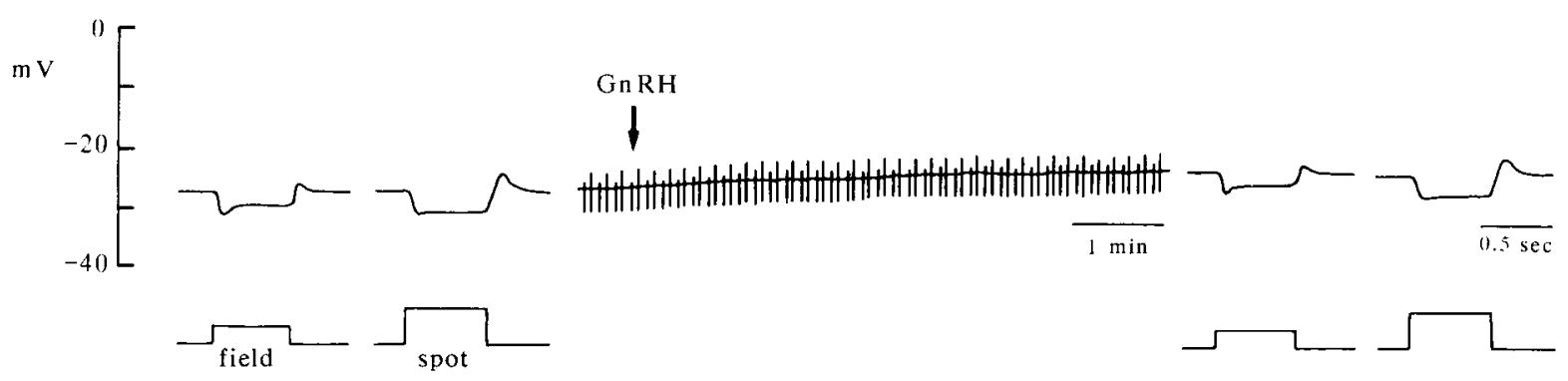

Figure 6. Effects of GnRH in a 6-OHDA-treated retina. Mammalian GnRH (40 $\mu \mathrm{M})$ was applied at the arrow, and it had no significant effects on membrane potential or the light-evoked responses. $\log I_{F}=-3.7 ; \log I_{S}=-2.0$. 
to light sensitize the retina. The horizontal cells again hyperpolarized, and there was an increase of response amplitudes (not shown). When GnRH was applied under conditions of prolonged darkness, horizontal cells neither hyperpolarized nor increased their responsiveness to light stimuli.

Only in one prolonged-darkness experiment (i.e., Fig. 9) did we succeed in recording from a horizontal cell for the approximately $60 \mathrm{~min}$ required for FMRFamide to exert its effects and for recovery to be completed. In four other prolonged-darkness experiments, we recorded responses from two or more cells successively during FMRFamide application and obtained results similar to those shown in Figure 8 . That is, in the presence of FMRFamide, horizontal cell membrane potentials typically hyperpolarized and light-evoked responses became larger; following reintroduction of control Ringer's solution, the cells depolarized and responses became smaller.

\section{Bicuculline and glycine}

GABA is a major inhibitory transmitter in the inner plexiform layer of the retina. Previously, it was shown that the GABA antagonist bicuculline shrinks the receptive field of horizontal cells in the carp retina much as dopamine does (Negishi et al., 1983). A plausible explanation for this result is that GABA antagonists induce dopamine release from interplexiform cells that are tonically inhibited by GABAergic amacrine cells (O'Connor et al., 1986; Ishita et al., 1988). Here, we have confirmed and extended these results. A total of 47 retinal preparations were studied in the experiments involving bicuculline, and a typical experiment is shown in Figure 10. After the introduction of bicuculline (arrow), the horizontal cell typically depolarized slightly after a short delay of 15-20 sec, but then the membrane potential returned to the baseline level. During this transient depolarization, the amplitudes of the responses to spot and full-field potential remained about the same. Subsequently, the horizontal cell depolarized again very slowly, and spot responses became significantly larger. The responsiveness of cells also decreased, as shown by a decline in the amplitude of responses to full-field stimuli. The effects of bicuculline werc irreversible, even with minimal effective concentrations.

To test whether the effects of hicuculline resulted from the release of dopamine from interplexiform cells, haloperidol was added to the Ringer's solution. In the presence of haloperidol, bicuculline produced almost no change in the responses to either spot or full-field illumination. However, the initial transient depolarization of the cell's membrane potential was still observed (see Fig. 12). We conclude that the shrinkage of the receptive field, the loss of light responsiveness, and the slow depolarization all result from the release of dopamine from interplexiform cells by bicuculline, but that the initial transient depolarization of membrane potential does not reflect a dopaminergic mechanism (see Discussion).

Results described earlier suggested that FMRFamide can inhibit the GnRH-induced release of dopamine from interplexiform cells. FMRFamide, on the other hand, never suppressed the bicuculline-induced release of dopamine from interplexiform cells, whether FMRFamide was administered after the receptive field was decreased in size by bicuculline or whether the two agents were administered simultaneously.

Glycine, another major inhibitory neurotransmitter agent in the inner plexiform layer of the fish retina, also had no significant effects on horizontal cell activity at reasonable concentrations. High concentrations of glycine $(>15 \mathrm{~mm})$ slightly hyperpolar-
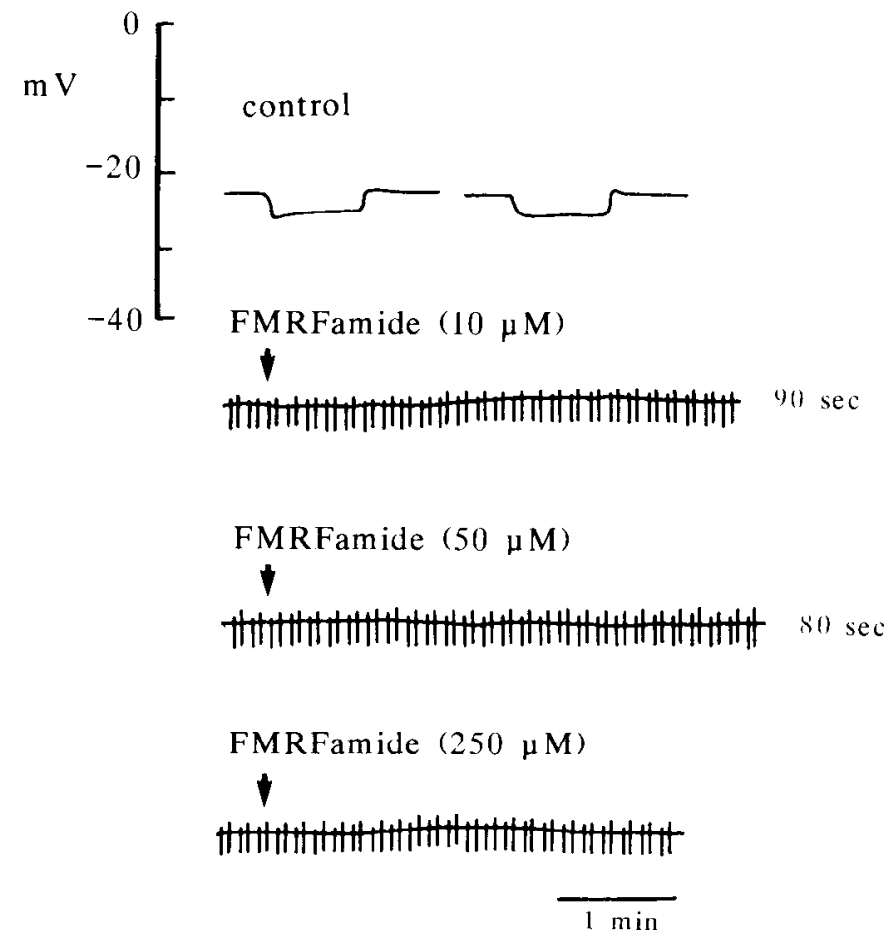

FMRFamide $(250 \mu \mathrm{M})$

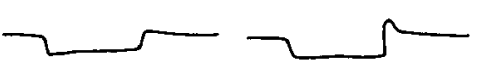

bicuculline

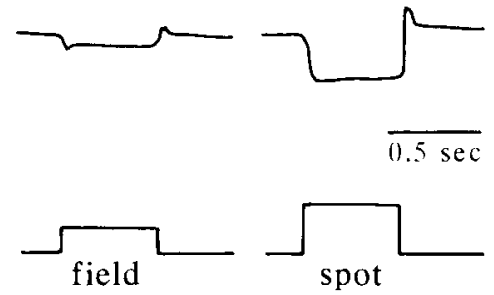

Figure 7. Effects of various concentrations of FMRFamide $(10,50$, and $250 \mu \mathrm{M}$ ) on a white perch horizontal cell. At the top is shown control responses at a fast recording specd. The next three traces, at a slow recording speed, show that FMRFamide at concentrations ranging from 10 to $250 \mu \mathrm{M}$ had no significant effects on either membrane potential or on the light-evoked responses. At the end of the experiment, bicuculline $(350 \mu \mathrm{M})$ was applied to the retina, and it caused effects similar to those of dopamine (see Fig. 10), indicating that the interplexiform cells were functional and capable of releasing dopamine. $\log I_{t}=-3.7$; $\log I_{S}=-2.5$.

ized horizontal cells $(\sim 5 \mathrm{mV})$, but similar hyperpolarizations were produced by glycine in the presence of haloperidol. No changes were seen in the light responses of horizontal cells during glycine-induced hyperpolarizations. GABA also caused horizontal cells to hyperpolarize, by as much as $20 \mathrm{mV}$ in some experiments (Wu and Dowling, 1980). However, responses to the light stimuli used in these experiments did not change significantly after GABA application to the retina (see Fig. 15).

\section{Enkephalin}

[D-Ala']-met-enkephalinamide applied to the retina typically caused a very slow depolarization of the membrane potential 


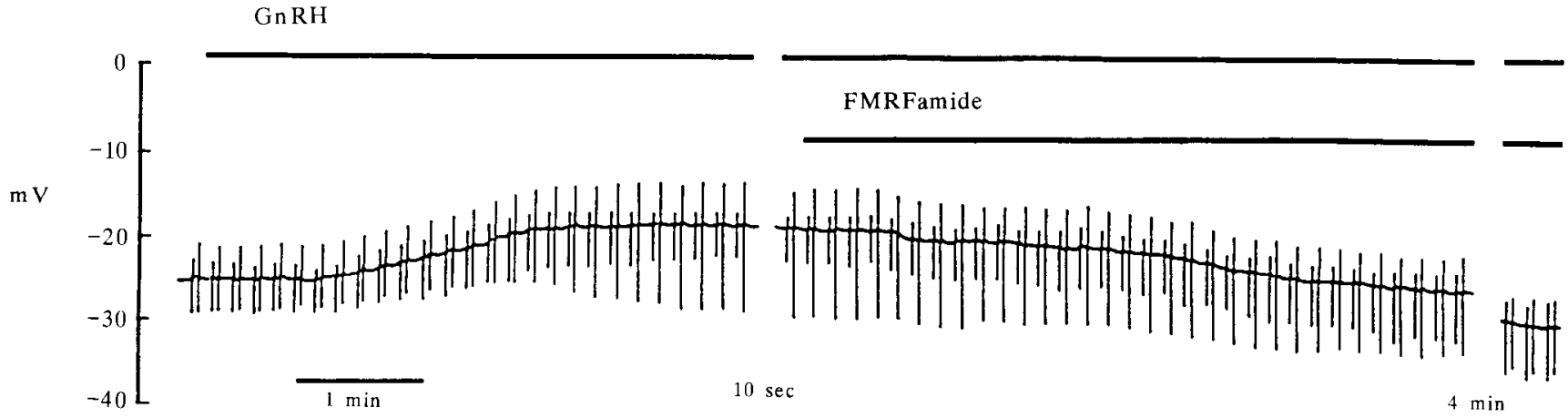

control

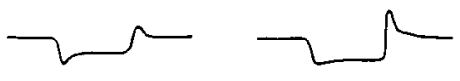

Gn RH

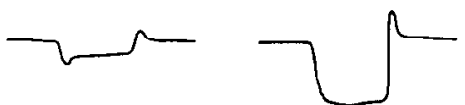

GnRH and FMRFamide
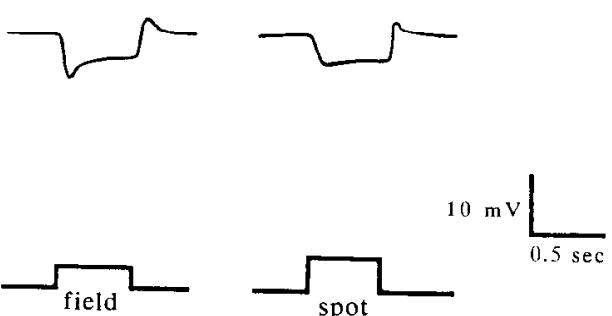

Figure 8. Antagonism of GnRH effects by FMRFamide. GnRH was first applied to the retina (left), and it caused effects on both the membrane potential and light responses of the cell. FMRFamide was applied during GnRH superfusion (right), and it reversed the GnRH effects; the cell hyperpolarized, and responses to spot illumination decreased, whereas responses to full-field illumination increased in amplitude. Log $I_{F}=-3.7$; $\log I_{S}=-2.0$.

a

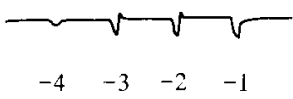

$\log I$ b

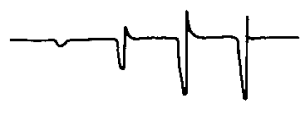

C

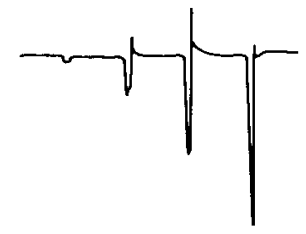

d

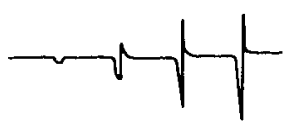

e

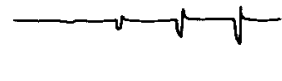

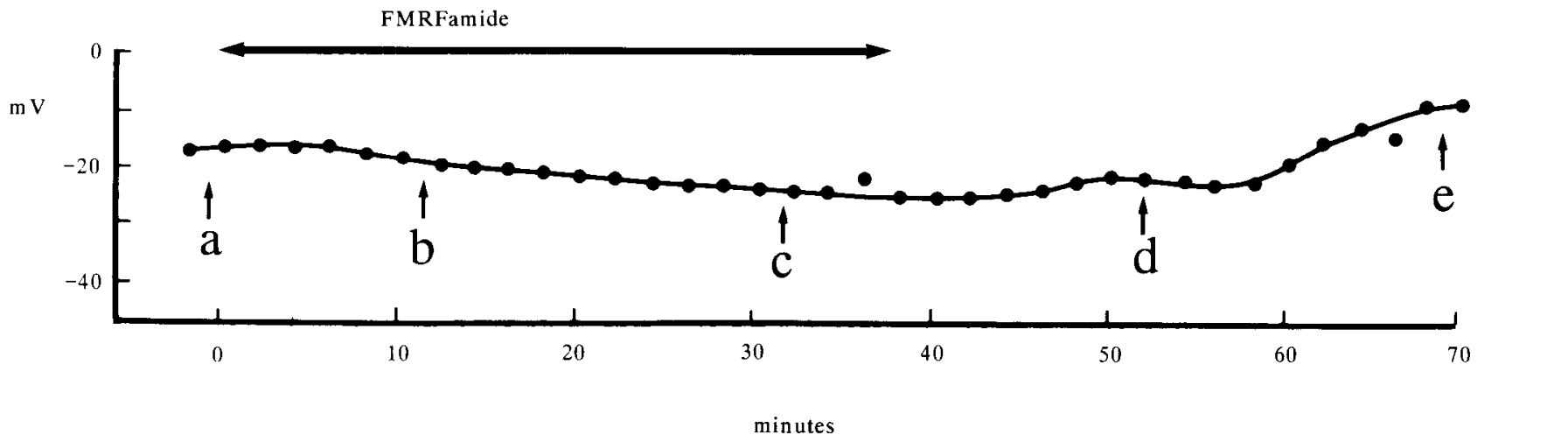

Figure 9. Effects of FMRFamide on a horizontal cell recorded in a retina maintained in prolonged darkness. The fish was kept in the dark for more than $2 \mathrm{hr}$ before the retina was isolated and the experiment was begun. The lower trace shows the changes in membrane potential during the course of the experiment. The upper traces show responses to full-field flashes $(500 \mathrm{msec})$ of increasing intensity recorded at the times indicated $(a-e)$. FMRFamide $(40 \mu \mathrm{M})$ application was started at the time 0. FMRFamide caused the cell to hyperpolarize. Furthermore, its light responsiveness increased dramatically in amplitude during FMRFamide superfusion. When FMRFamide superfusion ceased, the effects reversed. 
$\mathrm{mV}$

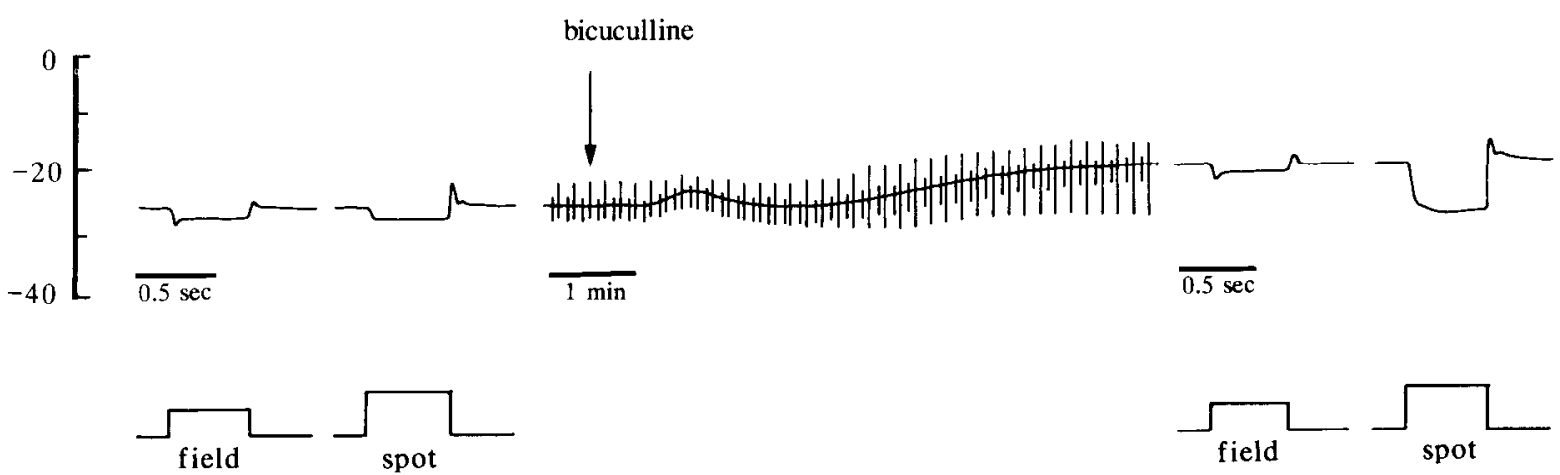

Figure 10. Effects of bicuculline on a white perch horizontal cell. Bicuculline $(\sim 350 \mu \mathrm{M})$ induced an initial transient depolarization of the cell, followed by a more sustained depolarization. During the slow depolarization, responses to spot illumination increased in amplitude, whereas responses to full-field illumination decreased in amplitude. $\log I_{F}=-3.5 ; \log I_{s}=-2.2$.

of horizontal cells (Fig. 11). Furthermore, responses to spot stimuli increased in amplitude, whereas responses to full-field illumination decreased in size. Thus, the effects of [D-Ala $\left.{ }^{2}\right]-$ metenkephalinamide on horizontal cells were similar to those of dopamine except that the effects of [D-Ala $\left.{ }^{2}\right]$-met-enkephalinamide were much slower, longer lasting, and usually irreversible. To test whether [D-Ala $\left.{ }^{2}\right]$-met-enkephalinamide stimulates the release of dopamine from interplexiform cells, we applied [D$\mathrm{Ala}^{2}$ ]-met-enkephalinamide to the retina in the presence of haloperidol. As shown in Figure 12, [D-Ala $\left.{ }^{2}\right]$-met-enkephalinamide had no effects on horizontal cells when the Ringer's solution contained haloperidol. In the experiment shown in Figure 12, bicuculline was also applied to the retina. Bicuculline depolarized the horizontal cell's membrane, but it did not affect the responses of the cell to either full-field or spot stimuli.

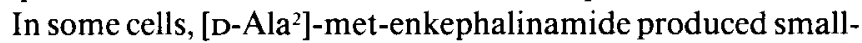
cr cffects than those scen in Figure 11, but in all cells tested some effects of enkephalin were seen $(n=31)$. Interestingly, the effects of [D-Ala $\left.{ }^{2}\right]$-met-enkephalinamide on L-type horizontal cells were small when the effects of bicuculline were also small. This suggests that bicuculline and [D-Ala $\left.{ }^{2}\right]-m e t-e n k e p h a l i n a m-$ ide release dopamine from a common source, that is, the interplexiform cells. Like the effects of bicuculline, the effects of enkephalin were long lasting and usually irreversible.

The opiate antagonist naloxone also blocked the effects of [D-
Ala $\left.{ }^{2}\right]$-met-cnkephalinamidc. In the experiment shown in Figure 13, naloxone was first added to the retina (left arrow), followed by Ringer's containing both naloxone and [D-Ala $\left.{ }^{2}\right]$-met-enkephalinamide (right arrow). Naloxone completely inhibited the effects of $\left[\mathrm{D}-\mathrm{Ala}^{2}\right]-$ met-enkephalinamide. Later in this experiment, bicuculline was applied to the retina (not shown), and this agent affected both receptive field size and light responsiveness of the horizontal cell. In other experiments, [D-Ala ${ }^{2}$ met-enkephalinamide was applied during continuous perfusion with naloxone solution, and still no effects on horizontal cells were observed. These results indicate that $\left[\mathrm{D}-\mathrm{Ala}^{2}\right]-$ met-enkephalinamide exerts its effects via opiate receptors.

We also examined the effects of [D-Ala $\left.{ }^{2}, \mathrm{D}-\mathrm{Leu}^{5}\right]$-enkephalin and [D-Ala ${ }^{2}$-leu-enkephalinamide on horizontal cells using a similar experimental protocol, but neither peptide showed any effect on either the membrane potential or light-evoked response amplitudes ( $n=4$ for [D-Ala?, D-Leu]-enkephalin; $n=3$ for [DAla ${ }^{2}$-leu-enkephalinamide). In one experiment, shown in Figure 14, three different concentrations $(20,40$, and $80 \mu \mathrm{M})$ of [D$\left.\mathrm{Ala}^{2}\right]$-leu-enkephalinamide were applied to the retina. No effects were seen with any concentration. Bicuculline was also applied to show that the interplexiform cells were functional in the retina and could release dopamine. As expected, bicuculline decreased the receptive field size and light responsiveness of horizontal cells.

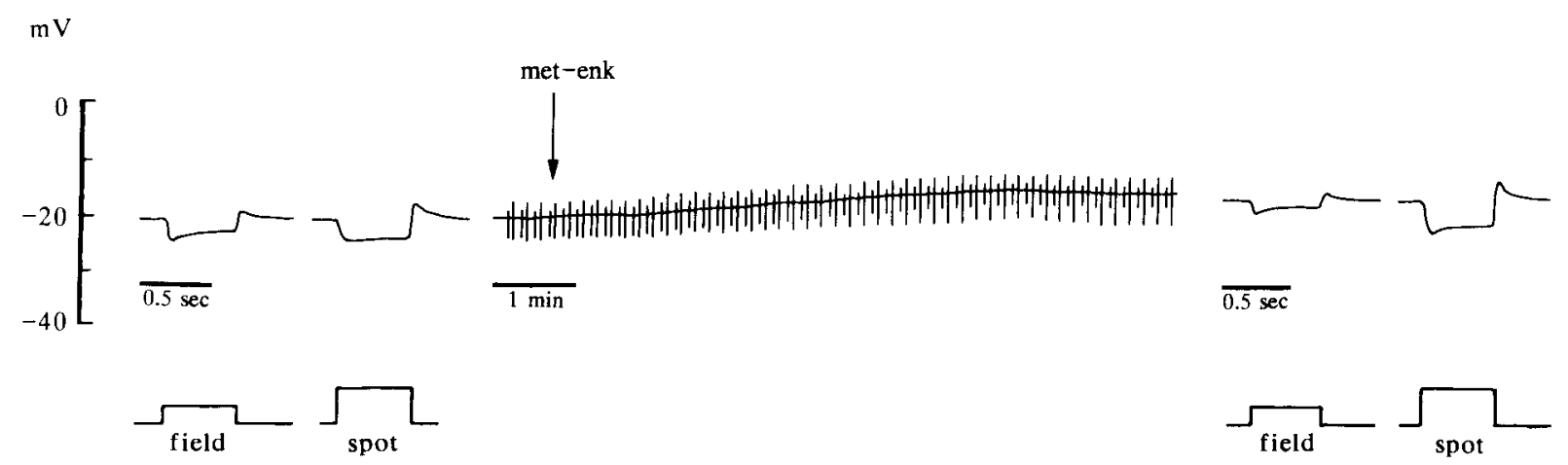

Figure 11. Effects of $\left[\mathrm{D}-\mathrm{Ala}^{2}\right]-$-met-enkephalinamide (met-enk; $\left.40 \mu \mathrm{M}\right)$ on a white perch horizontal cell. Met-enkephalin induced a very slow, small depolarization of the cell. In addition, responses to full-field illumination decreased in amplitude, whereas responses to spot illumination increased in amplitude. $\log I_{F}=-3.7 ; \log I_{S}=-2.2$. 


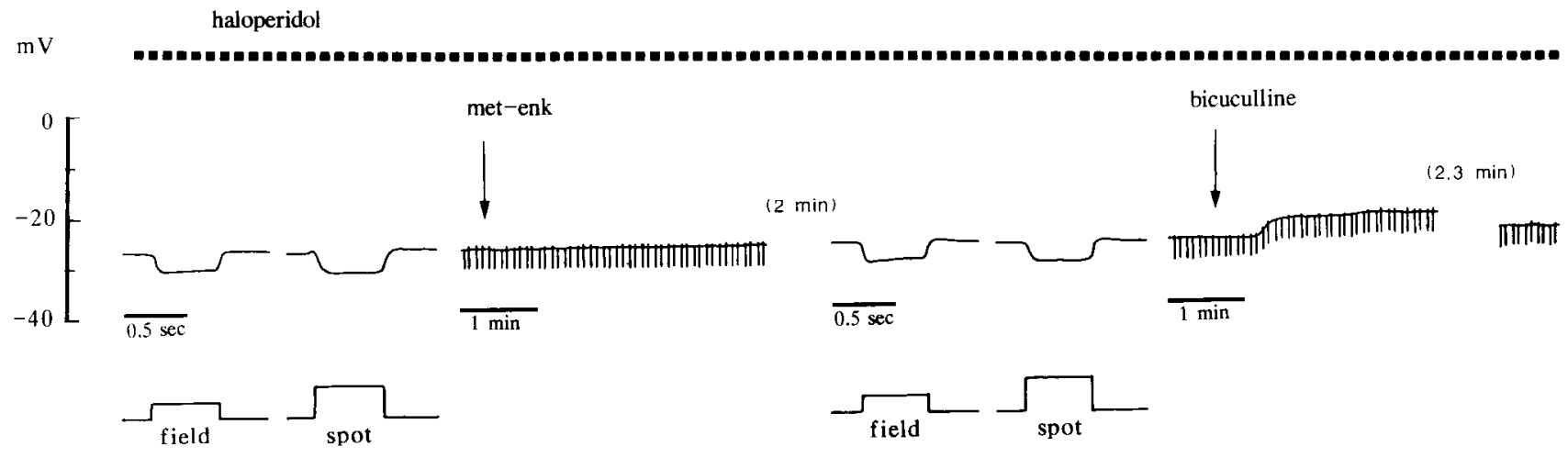

Figure 12. Haloperidol blocks the effect of [D-Ala $]$-met-enkephalinamide (met-enk). The retina was maintained for 30 min in Ringer's solution containing haloperidol before [D-Ala $]$-met-enkephalinamide was applied. No changes in membrane potential or light responses were observed in response to $\left[\mathrm{D}-\mathrm{Ala} \mathrm{a}^{2}\right.$-met-enkephalinamide. Bicuculline $(\sim 350 \mu \mathrm{M})$ applied at the end of the experiment depolarized the cell slightly but had no effects on the cell light responses, verifying haloperidol's efficacy as a dopamine antagonist in the experiment. $\log I_{F}=-3.4 ; \log I_{S}=-2.3$.

\section{Interactions between $G A B A$ and enkephalin}

Previous morphological and biochemical studies have indicated a close relationship between enkephalin and GABAergic amacrine cells in the teleost retina (Djamgoz et al., 1981; Su et al., 1986). To explore possible interactions between these two pharmacological agents, we applied [D-Ala $\left.{ }^{2}\right]$-met-enkephalinamide to the retina in the presence of GABA (Fig. 15). GABA caused the horizontal cell to hyperpolarize from its resting level of -27 $\mathrm{mV}$ to $-45 \mathrm{mV}$. [D-Ala ${ }^{2}$-met-enkephalinamide was applied after the retina had been exposed to GABA for approximately $3.5 \mathrm{~min}$. As shown in Figure 15, [D-Ala ${ }^{2}$ ]-met-enkephalinamide caused effects on the horizontal cell similar to the effects it caused on horizontal cells not exposed to GABA $(n=3)$. These results suggest that enkephalin acts on the interplexiform cells independently of GABA.

Another interesting and potentially important observation shown in Figure 15 is that the effects of [D-Ala $\left.{ }^{2}\right]$-met-enkephalinamide were completely reversible in the Ringer's solution containing GABA $(n=3)$. As noted earlier, the effect of [D$\left.\mathrm{Ala}^{2}\right]$-met-enkephalinamide was always irreversible when applied alone to the retina. Thus, the effects of enkephalin on interplexiform cells appear to be reversible when interplexiform cells are strongly inhibited by GABA.

\section{Discussion}

\section{GnRH and FMRFamide}

We have observed that dopamine and GnRH exert very similar effects on horizontal cells. Since the effect of GnRH can be blocked by dopamine antagonists, or by depleting the retina of dopamine with 6-OHDA, we conclude that the effect of GnRH on horizontal cells is mediated via dopamine. In other words, GnRH causes the release of dopamine in the retina. Anatomical studies have shown that peptides similar to GnRH and FRMFamide are present in the terminals of centrifugal fibers (Munz et al., 1982; Stell et al., 1984). These fibers synapse onto dopaminergic interplexiform cells, which in turn contact cone horizontal cells. Thus, it is likely that GnRH directly promotes the release of dopamine from interplexiform cells. It must be noted that the centrifugal fibers also synapse on amacrine cells. Thus, GnRH could also be acting on the interplexiform cells through other, more indirect pathways.

It has been suggested that distal retinal neurons are susceptible to central influences via the centrifugal fibers and interplexiform cells in the fish retina (Zucker and Dowling, 1987), and the present study provides supporting evidence for this hypothesis. The lowest effective concentration of GnRH needed to exert

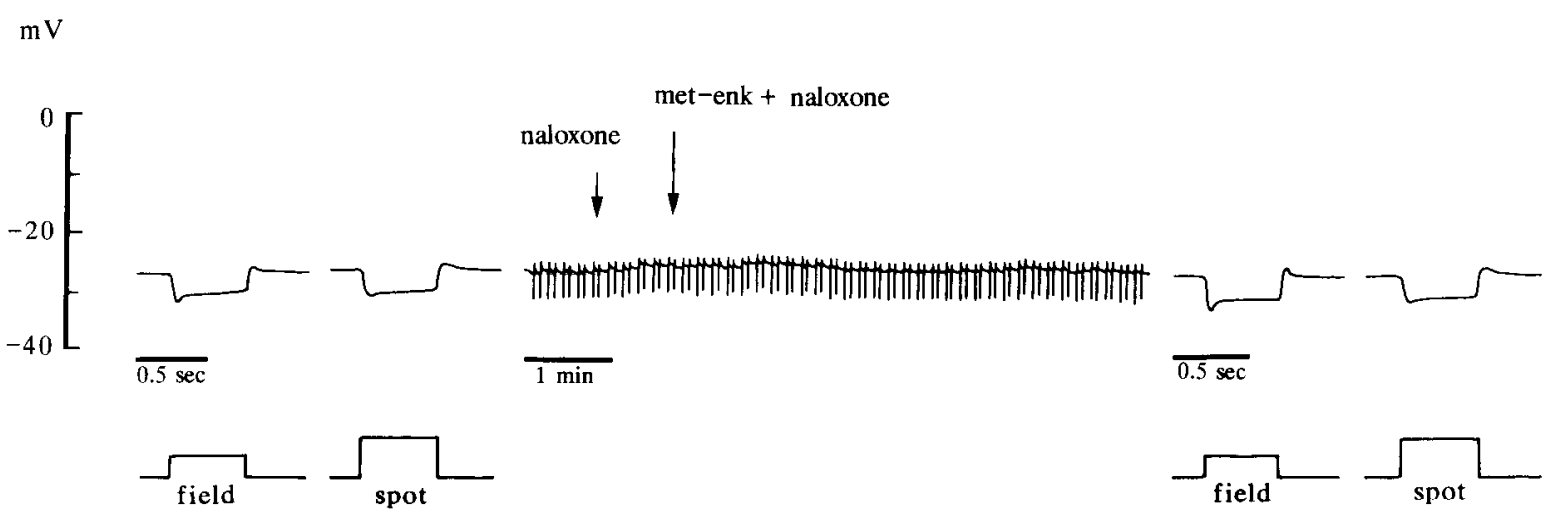

Figure 13. Naloxone blocks the action of $\left[\mathrm{D}-\mathrm{Ala}^{2}\right]-$ met-enkephalinamide (met-enk). Naloxone $(\sim 20 \mu \mathrm{M})$ was applied about 1 min prior to the application of Kinger's solution containing both naloxone $(\sim 20 \mu \mathrm{M})$ and $\left[\mathrm{D}-\mathrm{Ala} \mathrm{a}^{2}\right]$-met-enkephalinamide $(40 \mu \mathrm{M})$. No significant changes in membrane potential nor in the light-evoked responses were subsequently observed. $\log I_{r}=-3.7 ; \log I_{S}=-2.0$. 
effects was $0.02-0.1 \mu \mathrm{M}$, supporting the candidacy of a GnRHlike peptide as a neuroactive substance involved in such a pathway. Furthermore, the effects of $\mathrm{GnRH}$ were blocked by the GnRH antagonist [D-Phe ${ }^{2}$, Pro $^{3}$, D-Phe $\left.^{6}\right]-\mathrm{GnRH}$, indicating that GnRH was not acting directly on horizontal cells.

In contrast to the reliable effects of $\mathrm{GnRH}$ on horizontal cell activity, effects of FMRFamide were not consistent. FMRFamide clearly antagonized the effect of $\mathrm{GnRH}$ in the late autumn, but identical experiments conducted at other times of the year failed to demonstrate the same antagonistic effects. Inconsistent effects of FMRFamide were also reported in ganglion cell experiments conducted by Walker and Stell (1986). They found that FMRFamide was usually excitatory to ganglion cells, but that it could also be inhibitory or induce mixed excitatoryinhibitory effects. At present, it is difficult to explain these inconsistencies, but it was proposed that the action of FMRFamide might correlate with seasonal sexual and reproductive activity of the fish (Walker and Stell, 1986).

Since GnRH consistently affected horizontal cells whereas FMRFamide sometimes did not, it seems likely that these peptides act on different receptors in the interplexiform cell membrane. In the terminals of centrifugal fibers, GnRII and FMRFamide are both present within large vesicles. Thus, both peptides could be released simultaneously. However, when both peptides are applied together, they often cancel each other's effects. This raises the obvious question of the significance of a terminal simultaneously releasing an excitatory and an inhibitory agent. At present, we do not have an answer to this question, but two possibilities are suggested: (1) the ratios of GnRH and FMRFamide within the vesicles in the centrifugal fiber terminals vary depending on physiological conditions or time of day or year (see, e.g., La Gamma et al., 1984; Jung and Scheller, 1991), or (2) the sensitivity of the peptide receptors on the interplexiform cells changes under different conditions. It should be noted that, in addition to large vesicles, small vesicles have also been observed in the terminals of centrifugal fibers (Zucker and Dowling, 1987; Kawamata et al., 1990), a finding that suggests the presence of a third neuroactive substance in the centrifugal fibers. Thus, synaptic transmission from centrifugal fibers to interplexiform cells might be more complex than appreciated so far.

It is of interest to speculate on the functional role of the centrifugal pathways in fish. We have provided evidence that, in the dark, dopamine appears to be maximally released from interplexiform cells (Mangel and Dowling, 1985; Tornqvist et al., 1988; Yang et al., 1988a,b), whereas in a steady mesopic or light-adapted state, dopamine release from interplexiform cells appears to be low (Mangel and Dowling, 1987; Baldridge and Ball, 1991; Umino and Dowling, 1991). In the present study, GnRH mimicked the effects of dopamine in light-sensitized retinas but caused no effects in prolonged dark-adapted retinas. In contrast, FMRFamide demonstrated no effects in light-sensitized retinas but mimicked light-sensitization effects when applied under conditions of prolonged darkness. These observations suggest that GnRH released from centrifugal fibers stimulates dopamine release from interplexiform cells, but that FMRFamide inhibits dopamine release. Thus, the centrifugal fibers and the peptides they contain may be capable of modulating the release of dopamine under both dark and light conditions, that is, when dopamine release from the interplexiform cells is low (light-sensitized conditions) or when it is high (prolonged dark conditions).
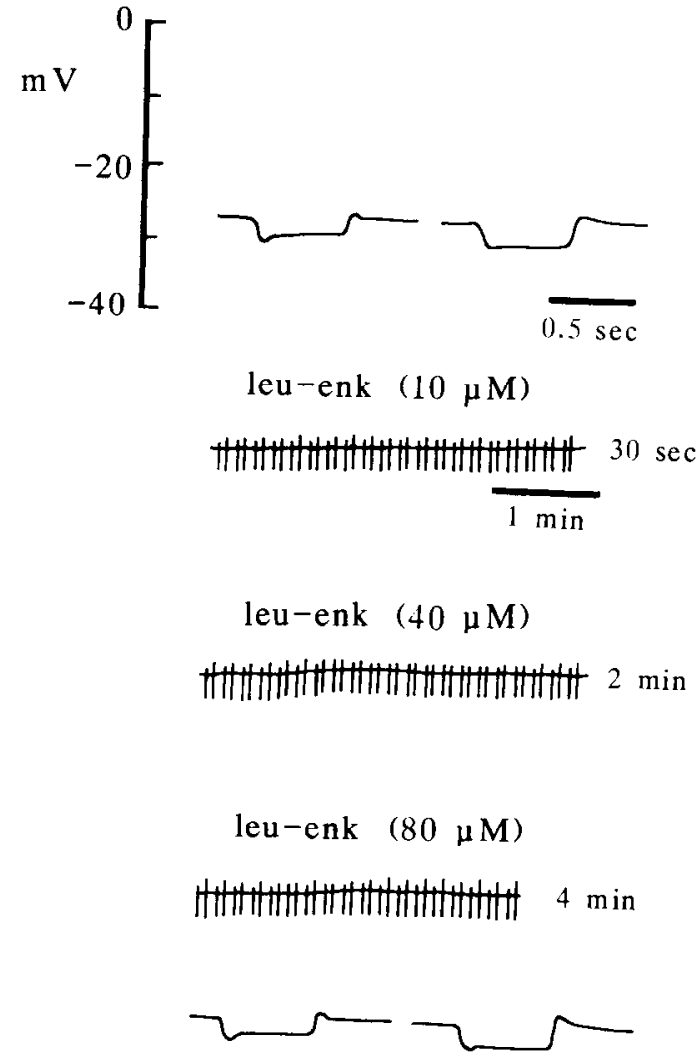

bicuculline
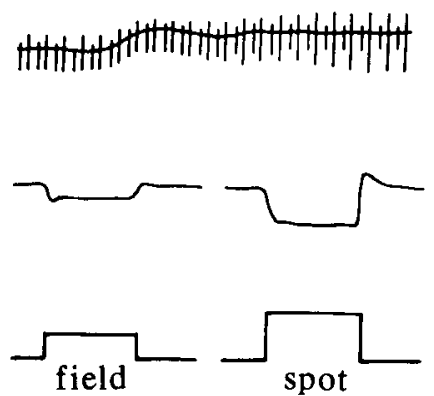

Figure 14. [D-Ala $\left.{ }^{2}\right]-l e u-e n k e p h a l i n a m i d e ~(l e u-e n k)$ has no significant effects on horizontal cells. Leu-enkephalin was applied at three different concentrations (from top to bottom, 10, 40, and $80 \mu \mathrm{M}$ ). Bicuculline $(\sim 350 \mu \mathrm{M})$ was applied at the end of the experiment (bottom two traces), and it caused its usual effects (see Fig. 10), indicating that the interplexiform cells were functional and capable of releasing dopamine in this retina. $\log I_{F}=-3.8 ; \log I_{S}=-2.2$.

\section{Bicuculline and enkephalin}

In the teleost retina, GABA is likely to be a neurotransmitter for both horizontal and amacrine cells (Lam and Steinman, 1971; Marc et al., 1978; Yazulla and Kleinschmidt, 1983), indicating that GABA is involved in signal processing in both the outer and inner plexiform layers. In accord with earlier results (Piccolino et al., 1982; Negishi et al., 1983), we have found that bicuculline mimics the effect of dopamine in shrinking the receptive field size of horizontal cells. We have also shown that bicuculline, like dopamine, also decreases the light responsiveness of horizontal cells. In addition, bicuculline causes hori- 
$\mathrm{mV}$

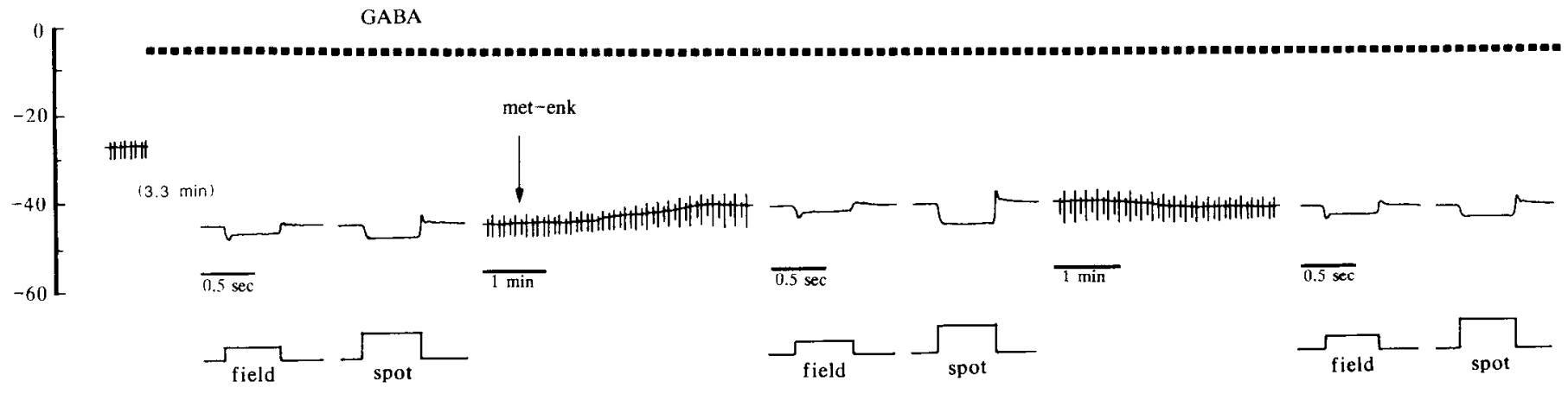

Figure 15. Effects of GABA on a white perch horizontal cell and the response of the cell to met-enkephalin (met-enk) in the presence of GABA. The cell initially had a resting potential of $-27 \mathrm{mV}$. GABA $(150 \mu \mathrm{M})$ hyperpolarized the cell to approximately $-45 \mathrm{mV}$, but its light responses were virtually unchanged in the presence of GABA. When a pulse of met-enkephalin $(\sim 40 \mu \mathrm{M})$ was applied to the retina, the cell depolarized, and responses to full-field illumination decreased in amplitude, whereas responses to spot illumination increased in amplitude. These effects were transient; within 6 min after the application of met-enkephalin, the membrane potential and light responses had recovered to predrug levels. Log $I_{F}=-3.5 ; \log I_{S}=-2.5$.

zontal cells to depolarize, but these effects are more complicated than those induced by dopamine.

The bicuculline-induced depolarizations in horizontal cells usually began with an initial fast depolarization followed by a slower depolarization. In the presence of haloperidol, bicuculline transiently depolarized horizontal cells but had virtually no effects on their responses to light stimuli, nor did it cause the slow depolarization in the presence of haloperidol, suggesting that the early depolarizing effects may reflect an action of bicuculline in the outer plexiform layer. In chromaticity-type horizontal cells, we observed that bicuculline eliminated the response to red light during the period corresponding to the initial

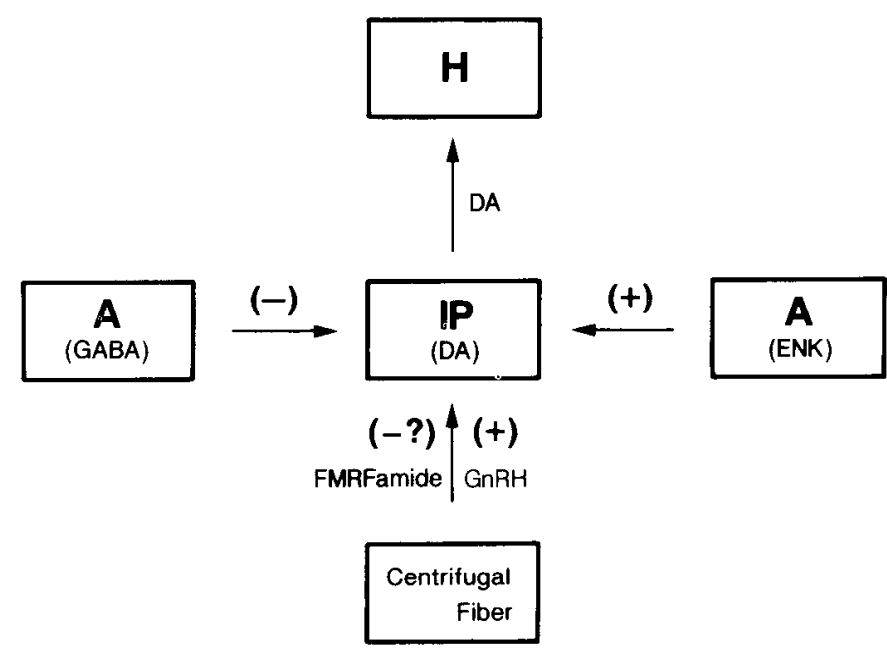

Figure 16. A schematic diagram illustrating the inputs to interplexiform cells in the white perch retina and their effect on dopamine release. Interplexiform cells receive input from amacrine cells and centrifugal fibers. GnRH, present in centrifugal fiber terminals, stimulates the release of dopamine $(D A)$ from interplexiform cells, whereas FMRFamide, also in centrifugal fibers, often antagonizes the effect of GnRH. GABAergic amacrine cells appear to inhibit tonically dopamine release from interplexiform cells, whereas met-enkephalinergic amacrine cells promote dopamine release from interplexiform cells. $H$, horizontal cells; $A$, amacrine cells; $I P$, interpiexiform cells. dcpolarization (O. Umino and J. E. Dowling, unpublished observations). It is believed that the red light-evoked response of chromaticity cells is produced by a GABAergic pathway in the outer plexiform layer (Murakami et al., 1978), providing more direct evidence that the initial depolarization of the horizontal cells by bicuculline is caused by an action mediated in the outer plexiform layer.

On the other hand, the decrease in receptive field size and light responsiveness induced by bicuculline, as well as the slow depolarization, were abolished by haloperidol, indicating that bicuculline causes the release of dopamine from interplexiform cells. Earlier studies directly measured the release of dopamine from the fish retinas in response to bicuculline (O'Connor et al., 1986) and showed in addition that dopamine is released from interplexiform cell processes in response to bicuculline (O'Connor et al., 1987).

The present results also indicate that met-enkephalin promotes dopamine release from interplexiform cells, indicating that the enkephalinergic amacrine cells are excitatory to the interplexiform cells. However, leu-enkephalin was not effective in releasing dopamine from the retina, indicating that the opioid receptors on interplexiform cells are specific for met-enkephalin. The enkephalins are generally thought to be inhibitory agents (for review, see North, 1979), which raises the question of how met-enkephalin releases dopamine from interplexiform cells. One possibility is that enkephalin acts as an inhibitory neuroactive substance in this system by acting on GABAergic or glycinergic amacrine cells that inhibit interplexiform cells (Djamgoz et al., 1981). GABA and enkephalin have been shown to coexist in a population of amacrine cells in the goldfish retina, and $\mathrm{Su}$ et al. (1986) have proposed that enkephalin inhibits GABA release from these amacrine cells by an autoregulatory mechanism. That GABA antagonists cause the release of dopamine in the teleost retina fits with this notion. However, we have shown that GABA effects on the interplexiform cells are independent of the enkephalin effects (see above), and also that glycine does not affect horizontal cells at reasonable concentrations. We presume, therefore, that met-enkephalin acts directly on interplexiform cells and in this way causes the release of dopamine. In the chicken retina, enkephalin has been reported to release ${ }^{3} \mathrm{H}$-dopamine (Ehinger et al., 1986), a result in accord 
with the present results. Su and Watt (1987), on the other hand, showed that opioid agonists can block the release of ${ }^{3} \mathrm{H}-\mathrm{dopa}$ mine from the chicken retina.

The effect of enkephalin was consistently observed at concentrations of $40 \mu \mathrm{M}$, but was never observed with concentrations lower than $10 \mu \mathrm{M}$. Peptide concentrations actually reaching the synapses are probably less than the concentration in the superfusion medium because of nonspecific peptide binding and diffusion barriers. In addition, enzymatic degradation may cause a large decrease in the concentration of enkephalin near opioid receptors, and such degradative enzymes are known to be located close to opioid receptors (Aoki et al., 1984).

A puzzling result of this study was that the effects of $\mathrm{GnRH}$, bicuculline, and enkephalin on horizontal cells were very long lasting and often irreversible, even when minimal concentrations of the agents were applied to the retina. All of these agents appear to affect the horizontal cells by stimulating dopamine release from interplexiform cells, but direct effects of dopamine on horizontal cells are reversible (Lasater and Dowling, 1985; Mangel and Dowling, 1987; DeVries and Schwartz, 1989). This suggests that these agents promote a very prolonged release of dopamine from interplexiform cells. Some support for this idea comes from experiments that have shown that ${ }^{3} \mathrm{H}$-dopamine is released from retinas for some time after a short application of bicuculline, whereas $\mathrm{K}^{+}$-induced release of ${ }^{3} \mathrm{H}$-dopamine is much more transient (O'Connor et al., 1986; Ishita et al., 1988). Furthermore, in rabbit, ${ }^{3} \mathrm{H}$-dopamine release caused by neuropeptide $Y$ has been shown to be prolonged (Bruun et al., 1986). A prolonged release of dopamine triggered by neuroactive agents may be common. An obvious question, then, is how the retina normally limits dopamine release. Our experiment examining the interaction between GABA and enkephalin provides a clue; Figure 15 showed that the effects of enkephalin on horizontal cells were reversible when applied in the presence of GABA, a finding that suggests that the action of enkephalin on interplexiform cells is reversible when the interplexiform cells are strongly inhibited by GABA.

Figure 16 summarizes the findings reported in this article. Of the retinal neurons, amacrine cells provide the main input to teleost interplexiform cells (Dowling and Ehinger, 1978); GABAergic amacrine cells appear to inhibit tonically the release of dopamine from interplexiform cells, whereas enkephalinergic amacrine cells appear to stimulate the release of dopamine from interplexiform cells. Interplexiform cells also receive input from centrifugal fibers originating from the olfactory bulb, and two peptides GnRH and FMRFamide are found in the terminals of these fibers (Zucker and Dowling, 1987). GnRH stimulates dopamine release from interplexiform cells, whereas FMRFamide often antagonizes the action of GnRH. The scheme shown in Figure 16 is probably the simplest possible. There may be additional amacrine cells interposed between the GABAergic amacrine cells, enkephalinergic amacrine cells, and interplexiform cells, and furthermore, interplexiform cells may receive direct input from other types of amacrine cells. For example, serotoninergic cells have been reported to release dopamine from the teleost retina (Kato et al., 1982), although this result was not confirmed subsequently (O'Connor et al., 1986). In addition, it is likely that the centrifugal fibers synapse on GABAergic amacrine cells and perhaps the enkephalinergic amacrine cells, as well. Finally, it is possible that the enkephalinergic amacrine cells that provide input to the interplexiform cells also contain GABA (Su et al., 1986).

\section{References}

Aoki K, Kajiwara M, Oka T (1984) The role of bestatin-sensitive aminopeptidase, angiotensin converting enzyme and thiorphan-sensitive "enkephalinase" in the potency of enkephalins in the guineapig ileum. Jpn J Pharmacol 36:59-65.

Baldridge WH, Ball AK (1991) Background illumination reduces horizontal cell receptive field size in both normal and 6-hydroxydopamine-lesioned goldfish retinas. Vis Neurosci, in press.

Baldridge WH, Ball AK, Miller RG (1987) Dopaminergic regulation of horizontal cell gap junction particle density in goldfish retina. $J$ Comp Neurol 265:428-436.

Bruun A, Ehinger B, Tornqvist K (1986) NPY immunoreactive neurons in the vertebrate retina. In: Retinal signal systems, degeneration and transplants (Agardh E, Ehinger B, eds), pp 89-103. Amsterdam: Elsevier.

DeVries SH, Schwartz EA (1989) Modulation of an electrical synapse between solitary pairs of catfish horizontal cells by dopamine and second messengers. J Physiol (Lond) 414:351-375.

Djamgoz MBA, Stell WK, Chin CA, Lam DMK (1981) An opiate system in the goldfish retina. Nature 292:620-623.

Dowling JE, Cowan WM (1966) An electron microscope study of normal and degenerating centrifugal fiber terminals in the pigeon retina. Z Zellforsch Mikrosk Anat 71:14-28.

Dowling JE, Ehinger B (1978) The interplexiform cell system. I. Synapses of the dopaminergic neurons of the goldfish retina. Proc $R$ Soc Lond [Biol] 201:7-26.

Dowling JE, Pak MW, Lasater EM (1985) White perch horizontal cells in culture: methods, morphology and process growth. Brain Res 360 : $331-338$

Ehinger B, Dowling JE (1987) Retinal neurocircuitry and transmission. In: Handbook of chemical neuroanatomy, Vol 5, Integrated systems of the CNS, Pt I (Bjorklund A, Hokfelt T, Swanson LW, eds), pp 389 446. Amsterdam: Elsevier.

Ehinger B, Tornqvist K, Waga J (1986) Neurotransmitter release by certain neuropeptides in the rabbit and chicken retina. In: Retinal signal systems, degenerations and transplants (Agardh E, Ehinger B, eds), pp 105-113. Amsterdam: Elsevier.

Hedden WL, Dowling JE (1978) The interplexiform cell system. II. Effects of dopamine on goldfish retinal neurons. Proc $\mathrm{R}$ Soc Lond [Biol] 201:27-55.

Ishita $S$, Negishi K, Teranishi T, Shimada Y, Kato S (1988) GABAergic inhibition on dopamine cells of the fish retina: $\mathrm{a}\left[{ }^{3} \mathrm{H}\right]$ dopamine release study with isolated cell fractions. J Neurochem 50:1-6.

Jung LJ, Scheller RH (1991) Peptide processing and targeting in the neuronal secretory pathway. Science 251:1330-1335.

Kaneko A (1971) Electrical connexions between horizontal cells in the dogfish retina. J Physiol (Lond) 213:95-105.

Kato S, Teranishi T, Kuo CH, Negishi K (1982) 5-Hydroxytryptamine stimulates $\left[{ }^{3} \mathrm{H}\right]$ dopamine release from the fish retina. J Neurochem 39:493-498.

Kawamata K, Ohtsuka T, Stell WK (1990) Electron microscopic study of immunocytochemically labeled centrifugal fibers in the goldfish retina. J Comp Neurol 293:655-664.

La Gamma EF, Adler JE, Black IB (1984) Impulse activity differentially regulates [Leu]enkephalin and catecholamine characters in the adrenal medulla. Science 224:1102-1104.

Lam DMK, Steinman L (1971) The uptake of $\left[{ }^{3} \mathrm{H}\right] \gamma$-aminobutyric acid in the goldfish retina. Proc Natl Acad Sci USA 68:2777-2881.

Lasater EM, Dowling JE (1985) Dopamine decreases conductance of the electrical junctions between cultured retinal horizontal cells. Proc Natl Acad Sci USA 82:3025-3029.

Mangel SC, Dowling JE (1985) Responsiveness and receptive field size of carp horizontal cells are reduced by prolonged darkness and dopamine. Science 229:1107-1109.

Mangel SC, Dowling JE (1987) The interplexiform-horizontal cell system of the fish retina: effects of dopamine, light stimulation and time in the dark. Proc R Soc Lond [Biol] 231:91-121.

Marc RE, Stell WK, Bok D, Lam DMK (1978) GABA-ergic pathways in the goldfish retina. J Comp Neurol 182:221-246.

Murz H, Class B, StumprWE, Jennes L (1982) Centrifugal innervation of the retina by luteinizing hormone releasing hormone (LHRH-immunoreactive telencephalic neurons in teleostean fishes). Cell Tissue Res 222:313-323.

Murakami M, Shimoda Y, Nakatani K (1978) Effects of GABA on 
neuronal activities in the distal retina of the carp. Sens Processes 2: 334-338.

Naka KI (1972) The horizontal cell. Vision Res 12:573-588.

Naka KI, Rushton WAH (1967) The generation and spread of S-potentials in fish (Cyprinidae). J Physiol (Lond) 192:437-461.

Negishi K, Drujan B (1979) Reciprocal changes in center and surrounding $\mathrm{S}$-potentials of fish retina in response to dopamine. Neurochem Res 4:313-318.

Negishi K, Teranishi T, Kato S (1981) Similarity in spatial distribution between dopaminergic cells and indoleamine-accumulating cells of carp retina. Acta Histochem Cytochem 14:449-460.

Negishi K, Teranishi T, Kato S (1983) GABA antagonist bicuculline exerts its uncoupling action on external horizontal cells through dopamine cells in carp retina. Neurosci Lett 37:261-266.

North RA (1979) Opiates, opioid peptides and single neurons. Life Sci 24:1527-1548.

O'Connor P, Dorison SJ, Watling KJ, Dowling JE (1986) Factors affecting release of ${ }^{3} \mathrm{H}$-dopamine from perfused carp retina. J Neurosci 6:1857-1865.

O'Connor P, Zucker CL, Dowling JE (1987) Regulation of dopamine rclease from interplexiform cell processes in the outer plexiform layer of the carp retina. J Neurochem 49:916-920.

Piccolino M, Neyton J, Witkovsky P, Gerschenfeld HM (1982) $\gamma$-Aminobutyric acid antagonists decrease junctional communication between L-horizontal cells of the retina. Proc Natl Acad Sci USA 79: $3671-3675$

Ramon y Cajal S (1911) Histologie du systeme nerveux de l'homme et des vertebres, Vol II. Paris: Maloine. Reprint, Madrid: Consejo Superior de Investigaciones Cientificas, Instituto Ramon y Cajal, 1955.

Stell WK, Walker SE, Chohan KS, Ball AK (1984) The goldfish nervous terminalis: a luteinizing hormone-releasing hormone and molluscan cardioexcitatory peptide immunoreactive olfactoretinal pathway. Proc Natl Acad Sci USA 81:940-944.

Su YYT, Watt CB (1987) Interaction between enkephalin and dopamine in the avian retina. Brain Res 63:423-463.

Su YYT, Fry KR, Lam DMK, Watt CB (1986) Enkephalin in goldfish retina. Cell Mol Neurobiol 6:331-347.

Teranishi T, Negishi K (1988) Regional difference in the dendritic morphology of dopamine cells. Brain Res 39:9-17.

Teranishi T, Negishi K, Kato S (1983) Dopamine modulates S-po- tential amplitude and dye-coupling between external horizontal cells in carp retina. Nature 301:243-246.

Tornqvist K, Yang XL, Dowling JE (1988) Modulation of cone horizontal cell activity in the teleost fish retina. III. Effects of prolonged darkness and dopamine on electrical coupling between horizontal cells. J Neurosci 8:2279-2288.

Toyoda J, Tonosaki K (1978) Effect of polarization of horizontal cells on the on-center bipolar cell of carp retina. Nature 276:399-400.

Umino O, Dowling JE (1988) The effect of LHRH and FMRFamide on horizontal cells in the white perch retina. Invest Ophthalmol Vis Sci 29:102.

Umino O, Dowling JE (1991) Effects of light stimuli on the release of dopamine from interplexiform cells in the white perch retina. Vis Neurosci, in press.

Walker SE, Stell WK (1986) Gonadotropin-releasing hormone (GnRF), molluscan cardioexcitatory peptide (FMRFamide), enkephalin and related neuropeptides affect goldfish retinal ganglion cell activity. Brain Res 384:262-273.

Weiler R, Kolbinger W, Kohler K (1989) Reduced light responsiveness of the cone pathway during prolonged darkness does not result from an increase of dopaminergic activity in the fish retina. Neurosci Lett 99:214-218

Werblin FS, Dowling JE (1969) Organization of the retina of the mudpuppy, Necturus maculosus. II. Intracellular recording. J Neurophysiol 32:339-355.

Wu SM, Dowling JE (1980) Effects of GABA and glycine on the distal cells of the cyprinid retina. Brain Kes 199:401-414.

Yang XL, Tornqvist K, Dowling JE (1988a) Modulation of cone horizontal cell activity in the teleost fish retina. I. Effects of prolonged darkness and background illumination on light responsiveness. J Neurosci 8:2259-2268

Yang XL, Tornqvist K, Dowling JF (1988b) Modulation of cone horizontal cell activity in the teleost fish retina. II. Role of interplexiform cells and dopamine in regulating light responsiveness. J Neurosci 8 : $2269-2278$

Yazulla S, Kleinschmidt J (1983) Carrier-mediated release of GABA from retinal horizontal cells. Brain Res 263:63-75.

Zucker CL, Dowling JE (1987) Centrifugal fibers synapse on dopaminergic interplexiform cells in the teleost retina. Nature 330:166168. 